\title{
Sintesis dan Potensi Aktivitas Tabir Surya Senyawa Analog Kalkon Turunan 3'-Hidroksiasetofenon dan 4-Metoksibenzaldehid
}

\author{
Ihsan Ikhtiarudin ${ }^{1^{*}}$, Nesa Agistia ${ }^{1}$, Tria Harlianti ${ }^{1}$, Adel Zamri $^{2}$ \\ ${ }^{1}$ Program Studi Farmasi, Sekolah Tinggi Ilmu Farmasi Riau. \\ ${ }^{2}$ Jurusan Kimia, Fakultas Matematika dan Ilmu Pengetahuan Alam, Universitas Riau \\ *ihsanikhtiarudin@stifar-riau.ac.id
}

\begin{abstract}
Chalcone analogues have attracted the attention of researchers due to their various biological activities. In this study, a chalcone analogue, (E)-1-(3-hydroxyphenyl)-3-(4-methoxyphenyl)prop-2-en-1-on has been synthesized under microwave irradiation and its sunscreen activity has been evaluated by in vitro assay using 96-well microplate reader. Based on the in vitro assay, at concentration of $100-500 \mu \mathrm{g} / \mathrm{ml}$, the compound showed potential sunscreen activity with \%Te value of 5.49 - $0.04 \%$ (extra protection - sunblock), \%Tp value of 0.51-0.05\% (sunblock) and SPF value of 18.20 32.91 (ultra protection). The assay result showed that the (E)-1-(3-hydroxyphenyl)-3-(4-methoxyphenyl)prop-2-en-1-on has a potency to be developed as active ingredient in sunscreen product.
\end{abstract}

Key words: chalcone analogue, microwave irradiation, microplate reader, sunscreen, SPF value

Abstrak

Senyawa analog kalkon telah menarik perhatian bagi banyak peneliti dikarenakan memiliki beragam aktivitas biologis yang menarik. Pada penelitian ini, senyawa analog kalkon, (E)-1-(3-hidroksifenil)-3-(4-metoksifenil)prop-2-en-1-on telah disintesis dengan metode iradiasi microwave dan aktivitas tabir suryanya telah diuji secara in vitro menggunakan 96-well microplate reader. Berdasarkan pengujian in vitro, pada konsentrasi $100-500 \mu \mathrm{g} / \mathrm{ml}$ senyawa tersebut menunjukkan aktivitas tabir surya yang potensial dengan nilai \%Te sebesar 5,49 - 0,04 \% (proteksi ekstra - sunblock), nilai \%Tp sebesar 0,51 - 0,05 \% (sunblock) dan nilai SPF sebesar 18,20 - 32,91 (proteksi ultra). Hasil pengujian tersebut menunjukkan bahwa senyawa (E)-1-(3-hidroksifenil)-3-(4-metoksifenil)prop-2-en-1-on berpotensi untuk dikembangkan sebagai bahan aktif dalam sediaan tabir surya.

Kata kunci : Analog kalkon, iradiasi microwave, microplate reader, tabir surya, nilai SPF 


\section{PENDAHULUAN}

Paparan sinar matahari yang cukup dapat memberikan efek menguntungkan bagi tubuh manusia. Sinar matahari diperlukan dalam proses sintesis vitamin D di dalam tubuh (Husein-nezhad dan Holick, 2013; Holick, 2008), dan sebagai sumber energi (Kabira et al., 2018). Namun, disamping manfaat tersebut, paparan sinar matahari yang berlebihan juga dapat merugikan manusia, seperti berbagai kerusakan pada tubuh, termasuk luka bakar, photoaging dan kanker kulit (Lazópulos et al., 2018).

Menurut Wang (2008), sinar matahari yang dapat menembus lapisan ozon dibagi menjadi dua segmen, yaitu segmen UV A (320-400 $\mathrm{nm})$ dan segmen UV B $(290-320 \mathrm{~nm})$. Segmen UV A dapat masuk ke dalam lapisan dermis, menyebabkan kerusakan jaringan dermis sehingga mempercepat proses penuaan (photoaging), sedangkan segmen UV B dapat menyebabkan kerusakan kulit yang ditimbulkan berada di bawah lapisan epidermis, berupa luka bakar, dan juga kanker kulit. Oleh karena itu, untuk dapat melindungi tubuh dari dua segmen sinar tersebut, diperlukan sediaan tabir surya yang mengandung bahan aktif yang dapat menyerap sinar pada kedua daerah panjang gelombang tersebut.

Tabir surya pertama yang tersedia secara komersial dipasarkan pada tahun 1928 mengandung bahan aktif benzil salisilat dan benzil sinamat. Saat ini, senyawa-senyawa tersebut tidak hanya digunakan sebagai bahan aktif dalam tabir surya, tetapi juga telah digunakan dalam sejumlah besar produk kosmetik untuk perawatan kulit dan rambut (Shaath, 2005). Kemudian hingga tahun 2010, dilaporkan sekitar 55 senyawa telah disetujui di bebagai negara terkait penggunaannya sebagai bahan aktif tabir surya. Namun, hanya 10 senyawa saja yang disetujui secara global (Shaath, 2010).

Penemuan dan penggunaan bahan aktif tabir surya seringkali dihadapkan dengan beberapa permasalahan. Beberapa filter UVA yang telah disetujui oleh negara-negara di Amerika dan Eropa, seperti tert-butylmethoxydibenzoylmethane (avobenzone) kemudian ditemukan bersifat tidak stabil dan dapat mengalami fotodegradasi ketika terpapar oleh radiasi UV (Schwack dan Rudolph, 1995; Karlsson et al., 2009). Selain itu, senyawa tersebut ternyata juga tidak dapat digunakan dalam kombinasi dengan tabir surya tertentu karena dapat bereaksi dengan bahan aktif tabir surya lainnya (Sayre et al., 2005). Kemudian beberapa masalah lainnya yang tak kalah penting yaitu masalah polusi lingkungan. Penggunaan tabir surya di beberapa negara ternyata berdampak pada pencemaran lingkungan perairan. Perkembangan pesat kawasan objek wisata pantai di beberapa daerah menyebabkan meningkatnya jumlah penggunaan sediaan tabir surya, sehinga saat ini tabir surya dipertimbangkan sebagai salah satu polutan bagi perairan pantai (Tovar-Sanchez et al., 2013). Meskipun beberapa tabir surya diformulasikan tahan terhadap air, diperkirakan bahwa setelah 20 menit perendaman, sekitar 25\% komponen tabir surya dilepaskan ke air. Sehingga, beberapa efek negatif dari penggunaan tabir surya terhadap lingkungan telah dilaporkan beberapa tahun terakir ini. Salah satunya adalah dapat mengancam kelestarian ekosistem terumbu karang yang ada di sekitar kawasan perairan (Downs et al., 2016).

Kalkon merupakan prekursor senyawa-senyawa flavonoid dan dapat ditemukan pada beberapa spesies tumbuhan (Sahu et al., 2012). Senyawa ini diketahui memiliki beragam aktivitas biologis yang menarik. Beberapa kalkon alami seperti butein dan monospermoside telah dilaporkan dapat meningkatkan stabilitas avobenzone sebagai salah satu bahan aktif tabir surya (Lahorkar et al., 2014). Selain itu, beberapa analog kalkon sintetik tersubstitusi nitro (George dan Fellague, 2003) dan tersubstitusi hidroksi (Forestier et al., 1987) juga telah dipatenkan terkait potensi penggunaanya sebagai bahan aktif dalam beberapa produk kosmetik, karena memiliki aktivitas tabir surya yang baik. Penelitian lainnya juga menunjukkan bahwa senyawa analog kalkon tersubstitusi hidroksi dan metoksi, (E)-1-(2-hidroksifenil)-3-(4-metoksifenil)prop2-en-1-on juga menunjukkan nilai serapan maksimun yang mendekati nilai serapan maksimun 
dibenzoylmethane sebagai salah satu bahan aktif tabir surya (Lazópulos et al., 2018). Oleh karena itu, menjadi suatu hal yang menarik bagi banyak peneliti untuk mengeksplorasi potensi penggunaan senyawa tersebut sebagai bahan aktif pada sediaan tabir surya.

Senyawa analog kalkon dapat disintesis dengan beberapa metode konvensional, seperti metode penggerusan (Rateb dan Zohdi, 2009), pengadukan dengan magnetic stirrer (Ikhtiarudin, et al, 2014), dan refluks (Jung et al., 2017). Dalam beberapa kondisi, metode konvensional ini memiliki beberapa kelemahan, seperti selektivitas reaksi yang rendah (Patil, et al., 2009; Stoyanov et al., 2002) dan waktu reaksi yang relatif lebih lama, yaitu sekitar 12 hingga 24 jam (Britton et al., 2012; Ikhtiarudin, et al, 2014). Di sisi lain, sintesis dengan metode iradiasi microwave dapat meningkatkan selektivitas reaksi dan juga mempersingkat waktu reaksi (Razzaq dan Kappe, 2008). Hal ini tentunya membuat metode iradiasi microwave menjadi alternatif yang lebih menarik. Pada penelitian ini, kami tertarik untuk mengaplikasikan metode iradiasi microwave dalam mensintesis senyawa analog kalkon (E)-1-(3-hidroksifenil)-3-(4-metoksifenil)prop-2-en-1-on, kemudian melakukan evaluasi terhadap potensi aktivitas tabir surya senyawa tersebut meliputi penentuan nilai persentase transmisi eritema (\% Te), persentase transmisi pigmentasi (\% Tp) dan nilai Sun Protection Factor (SPF) secara in vitro dengan menggunakan microplate reader.

\section{METODE PENELITIAN}

\section{Alat dan Bahan}

Sintesis dilakukan menggunakan Microwave Samsung (ME109F). Jalannya reaksi diamati melalui analisis KLT menggunakan pelat silika gel $\mathrm{GF}_{254}$ (Merck). Noda pada pelat KLT diamati dengan bantuan lampu UV 254 dan $366 \mathrm{~nm}$ (Camag ${ }^{\mathrm{TM}}$ ). Titik leleh diukur dengan alat pengukur titik leleh Stuart Melting Point (SMP-10). Spektrum UV diukur dengan Spektrofotometer UV-Vis (Genesys 10S UV-VIS v4.002 2L9N175013). Spektrum FT-IR diukur dengan Spektrofotometer FT-IR (Shimadzu, IR Prestige-21). Spektrum ${ }^{1} \mathrm{H}$ NMR diukur dengan spektrometer NMR (Agilent, $500 \mathrm{MHz}$ ). Spektrum massa resolusi tinggi diukur dengan water LCT premier XE mode positif. Aktivitas tabir surya dievaluasi menggunakan 96-wells microplate reader (Epoch Biotech).

Bahan-bahan kimia yang digunakan yaitu 3'-hidroksiasetofenon (Merck), 4-metoksibenzaldehid (Merck), potassium hidroksida (Merck), asam klorida (Merck), aqua DM (Bratachem), indikator universal (Merck), kertas saring Whatman 42, dan beberapa pelarut organik seperti $n$-heksana, etil asetat, dikloro metana (DCM) dan etanol absolut (Merck).

Sintesis senyawa analog kalkon

Reaksi sintesis senyawa (E)-1-(3-hidroksifenil)-3-(4-metoksifenil)prop-2-en-1-on dapat dilihat pada gambar 1. Sebanyak 20 mmol 3'-hidroksiasetofenon dilarutkan dalam $20 \mathrm{ml}$ etanol absolut di dalam suatu erlenmenyer, kemudian ditambahkan dengan $50 \mathrm{ml}$ larutan $\mathrm{KOH}$ 6N dan dihomogenkan. Sebanyak 20 mmol 4-metoksibenzaldehid ditambahkan ke dalam larutan di atas dan selanjutnya campuran reaktan diiradiasi di dalam microwave menggunakan daya $180 \mathrm{~W}$. Jalannya reaksi diamati melalui uji KLT. Setelah reaksi selesai, campuran reaksi dinetralkan dengan penambahan larutan asam klorida $3 \mathrm{~N}$ hingga terbentuk endapan. Endapan kemudian disaring dengan corong Buchner dan padatan dikeringkan dalam desikator. Padatan crude product yang diperoleh diuji KLT untuk menentukan kemurniannya dan crude product dimurnikan dengan teknik rekristalisasi menggunakan pelarut etanol absolut panas. Selanjutnya, padatan hasil rekristalisasi ditentukan kemurnian dan sifat fisikanya melalui uji KLT, pengukuran titik leleh, dan analisis HPLC. Struktur senyawa murni hasil sintesis ditetapkan melalui analisis spektroskopi UV, FT-IR, 
${ }^{1}$ H NMR dan HRMS.

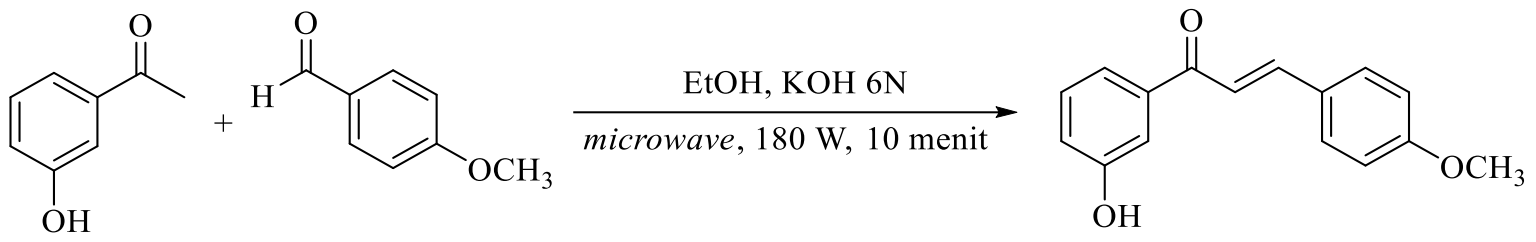

Gambar 1. Reaksi sintesis senyawa (E)-1-(3-hidroksifenil)-3-(4-metoksifenil)prop-2-en-1-on.

(E)-1-(3-hidroksifenil)-3-(4-metoksifenil)prop-2-en-1-on. Padatan berwarna kuning. Rendemen 71,18 \%. Titik leleh $129-131^{\circ} \mathrm{C}$. Kromatogram KLT: $\mathrm{R}_{\mathrm{f}}$ 0,23 (DCM 100\%), 0,68 (n-heksana:etil asetat $=$ 70:30), 0,80 (DCM: etil asetat = 85:15). Kromatogram HPLC: $t_{R}=11,728$ menit (Det. A Ch2: 340 nm). Spektrum UV (MeOH) $\left(\lambda_{\text {maks, }}\right.$ nm): 204, 223 (bahu), 238 (bahu), dan 343 nm. Spektrum FT-IR (KBr) $\left(v, \mathrm{~cm}^{-}\right.$ $\left.{ }^{1}\right): 3367,3023,2836,1649,1598,1551,1512,1448,1259$ dan 1162. Spektrum ${ }^{1} \mathrm{H}-\mathrm{NMR}\left(\mathrm{CDCl}_{3}, 500 \mathrm{MHz}\right)(\delta$, ppm): 7,80 (d, 1H, J = $16 \mathrm{~Hz}), 7,62(s, 1 \mathrm{H}), 7,59(d, 2 \mathrm{H}, J=8,5 \mathrm{~Hz}), 7,56(\mathrm{~d}, 1 \mathrm{H}, J=7,5 \mathrm{~Hz}), 7,39(d, 1 \mathrm{H}, J=$ $16 \mathrm{~Hz}), 7,37(t, 1 \mathrm{H}, J=8 \mathrm{~Hz}), 7,11\left(\mathrm{dd}, 1 \mathrm{H}, J_{1}=8 \mathrm{~Hz}, J_{2}=2,5 \mathrm{~Hz}\right), 6,93(d, 2 \mathrm{H}, J=8,5 \mathrm{~Hz}), 6,58(b r-s, 1 \mathrm{H}) \mathrm{dan}$ $3,85(s, 3 \mathrm{H})$. Spektum massa (HRMS, ES+): massa dihitung sebagai $\mathrm{C}_{16} \mathrm{H}_{15} \mathrm{O}_{3}[\mathrm{M}+\mathrm{H}]^{+}: 255,1021 \mathrm{~m} / \mathrm{z}$ dan ditemukan pada $\mathrm{m} / \mathrm{z}=255,1024 \mathrm{~m} / \mathrm{z}$.

Uji aktivitas tabir surya secara in vitro

\section{Penentuan nilai \%Te dan \%Tp}

Penentuan nilai \%Te dan \%Tp dilakukan dengan memodifikasi metode sebelumnya (Athiyah et al., 2015). Sebanyak $10 \mathrm{mg}$ sampel dilarutkan dalam $10 \mathrm{ml}$ etanol absolut, sehingga diperoleh larutan induk dengan konsentrasi $1000 \mu \mathrm{g} / \mathrm{mL}$. Kemudian larutan induk diencerkan menjadi konsentrasi $500 \mu \mathrm{g} / \mathrm{mL}$. Larutan $500 \mu \mathrm{g} / \mathrm{mL}$ tersebut dipipet masing-masing sebanyak 100, 80, 60, 40, dan $20 \mu \mathrm{l} \mathrm{ke} \mathrm{dalam} \mathrm{baris} A, B$, C, D, dan E. Kemudian sebanyak 20, 40, 60 dan $80 \mu$ l etanol absolut ditambahkan ke dalam baris B, C, D, dan E. Sehingga diperoleh konsentrasi larutan uji pada baris A $(500 \mu \mathrm{g} / \mathrm{ml}), \mathrm{B}(400 \mu \mathrm{g} / \mathrm{ml}), \mathrm{C}(300 \mu \mathrm{g} / \mathrm{ml}), \mathrm{D}$ $(200 \mu \mathrm{g} / \mathrm{ml})$, dan $\mathrm{E}(100 \mu \mathrm{g} / \mathrm{ml})$. Sumur baris $\mathrm{F}$ diisi dengan $100 \mu \mathrm{l}$ etanol absolut sebagai blangko. Absorbansi larutan dalam masing-masing sumur diukur dengan microplate reader pada panjang gelombang yang dapat menimbulkan eritema $(293-318 \mathrm{~nm})$ dan pigmentasi $(323-373 \mathrm{~nm})$ setiap interval 5 nm. Selanjutnya, untuk menghitung nilai \%Te dan \%Tp, nilai absorbansi (A) yang diperoleh, terlebih dahulu harus dikonversi menjadi nilai transmitan $(\mathrm{T})$ menggunakan persamaan berikut.

$$
A=-\log \mathrm{T}
$$

Selanjutnya, nilai $\mathrm{T}$ yang diperoleh dimasukkan ke persamaan berikut untuk menghitung nilai \% Te dan dan \% Tp. Dalam hal ini, Fe adalah nilai fluks eritema dan Fp adalah fluks pigmentasi. Nilai Fe dan Fp merupakan suatu konstanta dan dapat dilihat pada literatur sebelumnya (Balsam dan Sagarin, 1972).

$$
\begin{gathered}
\% \mathrm{Te}=\frac{\sum(\mathrm{T} \times \mathrm{Fe})}{\sum \mathrm{Fe}} \\
\% \mathrm{~T} \mathbf{p}=\frac{\sum(\mathrm{T} \times \mathrm{Fp})}{\sum \mathrm{Fp}}
\end{gathered}
$$


Tabir surya dikategorikan sebagai sunblock jika memiliki \%Te $<1 \%$ dan \%Tp 3-40 \%, proteksi ekstra jika memiliki \%Te 1-6 \% dan \%Tp 42-86 \%, suntan standar jika memiliki \%Te 6-12 \% dan \%Tp 45-86 \%, fast tanning jika memiliki \%Te 10-18 \% dan \%Tp 45-86 \% (Athiyah et al., 2015).

\section{Penentuan nilai SPF}

Penentuan nilai SPF dilakukan dengan memodifikasi metode sebelumnya (Dutra et al., 2004). Sebanyak $10 \mathrm{mg}$ sampel dilarutkan dalam $10 \mathrm{ml}$ etanol absolut, sehingga diperoleh larutan induk dengan konsentrasi $1000 \mu \mathrm{g} / \mathrm{mL}$. Kemudian larutan induk diencerkan menjadi konsentrasi $500 \mu \mathrm{g} / \mathrm{mL}$. Larutan 500 $\mu \mathrm{g} / \mathrm{mL}$ tersebut dipipet masing-masing sebanyak 100, 80, 60, 40, dan $20 \mu \mathrm{l}$ ke dalam baris $\mathrm{A}, \mathrm{B}, \mathrm{C}, \mathrm{D}, \mathrm{dan} \mathrm{E}$. Kemudian sebanyak 20, 40, 60 dan $80 \mu$ l etanol absolut ditambahkan ke dalam baris B, C, D, dan E. Sehingga diperoleh konsentrasi larutan uji pada baris A $(500 \mu \mathrm{g} / \mathrm{ml}), \mathrm{B}(400 \mu \mathrm{g} / \mathrm{ml}), \mathrm{C}(300 \mu \mathrm{g} / \mathrm{ml}), \mathrm{D}(200$ $\mu \mathrm{g} / \mathrm{ml})$, dan $\mathrm{E}(100 \mu \mathrm{g} / \mathrm{ml})$. Sumur baris $\mathrm{F}$ diisi dengan $100 \mu \mathrm{l}$ etanol absolut sebagai blangko. Absorbansi larutan pada masing-masing sumur diukur dengan microplate reader pada rentang panjang gelombang 290-320. Nilai absorbansi sampel pada masing-masing konsentrasi uji dicatat kemudian dihitung nilai SPF nya menggunakan persamaan Mansur (Mansur et al., 1986).

$$
\mathbf{S P F}=\mathbf{C F} \mathbf{x} \sum_{290}^{320} E E(\lambda) x I(\lambda) x A b s(\lambda)
$$

Dalam hal ini, CF adalah correction factor (faktor koreksi) yaitu 10. EE adalah Erythremal Effect (Spektrum efek eritema) dan I adalah Intensity (Spektrum intensitas matahari). Nilai EE $x$ I merupakan suatu konstanta dan dapat dilihat pada literatur sebelumnya (Dutra et al., 2004). Kemudian Abs adalah absorbansi sampel setelah dikurangi absorbansi blanko. Kekuatan proteksi suatu bahan tabir surya dikategorikan proteksi ultra jika nilai $S P F \geq 15$, proteksi maksimum jika nilai SPF 8 - $\leq 15$, proteksi ekstra jika nilai SPF 6 - $\leq$, proteksi sedang jika nilai SPF 4 - $<6$ dan proteksi minimal jika nilai SPF $2-<4$ (Sami et al., 2015).

\section{HASIL DAN PEMBAHASAN}

Sintesis analog kalkon

Pada penelitian ini, senyawa analog kalkon turunan 3'-hidroksiasetofenon dan 4metoksibenzaldehid, (E)-1-(3-hidroksifenil)-3-(4-metoksifenil)prop-2-en-1-on telah berhasil disintesis dengan metode iradiasi microwave. Metode iradiasi microwave dipilih karena memiliki berbagai keunggulan, seperti waktu reaksi yang lebih cepat, lebih mudah untuk dikontrol, lebih hemat energi, dan dapat meningkatkan rendemen produk, namun tidak pada semua kondisi reaksi (Bhuiyan et al., 2011; Zamri et al., 2016). Hasil pengamatan organoleptis dan sifat fisika dari senyawa analog kalkon tersebut dapat dilihat pada tabel 1.

Berdasarkan tabel 1, dapat dilihat bahwa titik leleh senyawa hasil sintesis memiliki selisih titik leleh yang tajam $\left(\leq 2^{\circ} \mathrm{C}\right)$, yang menunjukkan bahwa produk yang diperoleh telah murni. Kesimpulan ini diperkuat dengan kromatogram KLT yang menunjukkan bercak tunggal setelah dielusi dengan beberapa variasi eluen dengan nilai $R_{f}$ 0,23 (DCM 100\%), 0,68 (n-heksana: etil asetat = 70:30), 0,80 (DCM: etil asetat = 85:15). Selain itu, kromatogram HPLC juga menunjukkan puncak tunggal pada waktu retensi 11,728 menit pada panjang gelombang deteksi $340 \mathrm{~nm}$. 
Tabel 1. Hasil pengamatan organoleptis dan sifat fisika senyawa (E)-1-(3-hidroksifenil)-3-(4metoksifenil)prop-2-en-1-on

\begin{tabular}{llllc}
\hline & Bentuk & Warna & Rendemen (\%) & Titik leleh $\left({ }^{\circ} \mathrm{C}\right)$ \\
\hline & Kristal & Kuning & 71,18 & $129-131$ \\
\hline $\mathrm{OCH}_{3}$ & & & \\
\hline
\end{tabular}

Struktur senyawa analog kalkon hasil sintesis telah dikonfirmasi berdasarkan analisis spektroskopi UV, FT-IR, ${ }^{1} \mathrm{H}$ NMR dan spektrum massa resolusi tinggi. Spektrum UV senyawa analog kalkon menunjukkan serapan pada panjang gelombang 204 nm yang menunjukkan kehadiran kromofor benzena, serapan pada panjang gelombang 223 dan $238 \mathrm{~nm}$ yang merupakan serapan dari sistem konjugasi benzoil dan serapan pada panjang gelombang $343 \mathrm{~nm}$ yang merupakan serapan dari sistem konjugasi sinamoil yang merupakan karakteristik ikatan rangkap terkonjugasi pada senyawa kalkon, sebagaimana dapat dilihat pada gambar 2.

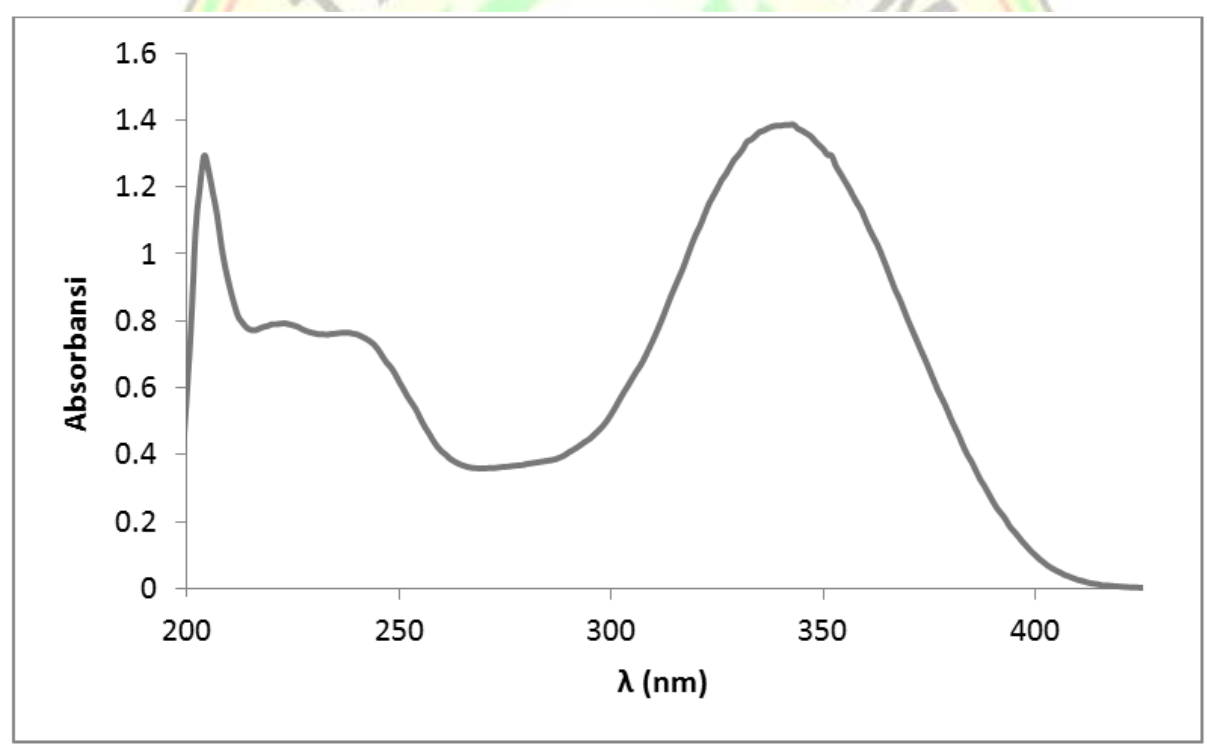

Gambar 2. Spektrum UV senyawa (E)-1-(3-hidroksifenil)-3-(4-metoksifenil)prop-2-en-1-on

Adanya gugus hidroksi $(\mathrm{OH})$ pada senyawa analog kalkon dikonfirmasi dengan munculnya pita serapan melebar pada spektrum FT-IR yaitu pada bilangan gelombang $3367 \mathrm{~cm}^{-1}$ sebagaimana dapat dilihat pada gambar 3. Hal ini diperkuat dengan munculnya puncak broad singlet $(\delta 6,58 \mathrm{ppm})$ dengan integrasi satu proton pada spektrum ${ }^{1} \mathrm{H}$ NMR, sebagaimana dapat dilihat pada gambar 4. Kehadiran gugus metoksi ($\mathrm{OCH}_{3}$ ) dikonfirmasi dengan munculnya beberapa pita serapan pada spektrum FT-IR yaitu pada bilangan gelombang $2836 \mathrm{~cm}^{-1}$ (C-H alifatik) dan $1259 \mathrm{~cm}^{-1}$ (C-O eter), serta diperkuat dengan munculnya puncak singlet pada spektrum ${ }^{1} \mathrm{H}$ NMR, dengan integrasi 3 proton pada $\delta 3,85 \mathrm{ppm}$. Selain itu, adanya gugus karbonil $(\mathrm{C}=\mathrm{O})$ keton terkonjugasi (etilen keto), yang merupakan karakteristik dari senyawa kalkon dikonfirmasi dengan munculnya pita serapan pada bilangan gelombang $1649 \mathrm{~cm}^{-1}$. Kemudian, kehadiran dua cincin aromatik pada kalkon dikonfirmasi dengan munculnya pita serapan pada spektrum FT-IR pada bilangan gelombang 1598, 1551, 1512 dan $1448 \mathrm{~cm}^{-1}(\mathrm{C}=\mathrm{C}$ aromatik) serta pita serapan pada bilangan 
gelombang $3024 \mathrm{~cm}^{-1}$ (C-H aromatik), kemudian diperkuat dengan munculnya sinyal-sinyal proton aromatik pada spektrum ${ }^{1} \mathrm{H}$ NMR pada pergeseran kimia 6,92-7,81 ppm. Kemudian kehadiran proton $\alpha, \beta$ yang menjadi ciri khas kalkon dikonfirmasi dengan munculnya dua puncak doublet pada spektrum ${ }^{1} \mathrm{H}$ NMR pada pergeseran kimia 7,80 dan 7,39 ppm, dan keduanya memiliki nilai konstanta coupling sebesar 16 Hz yang mengindikasikan bahwa senyawa analog kalkon tersebut memiliki geometri trans (E), sebagaimana disajikan pada gambar 4 .

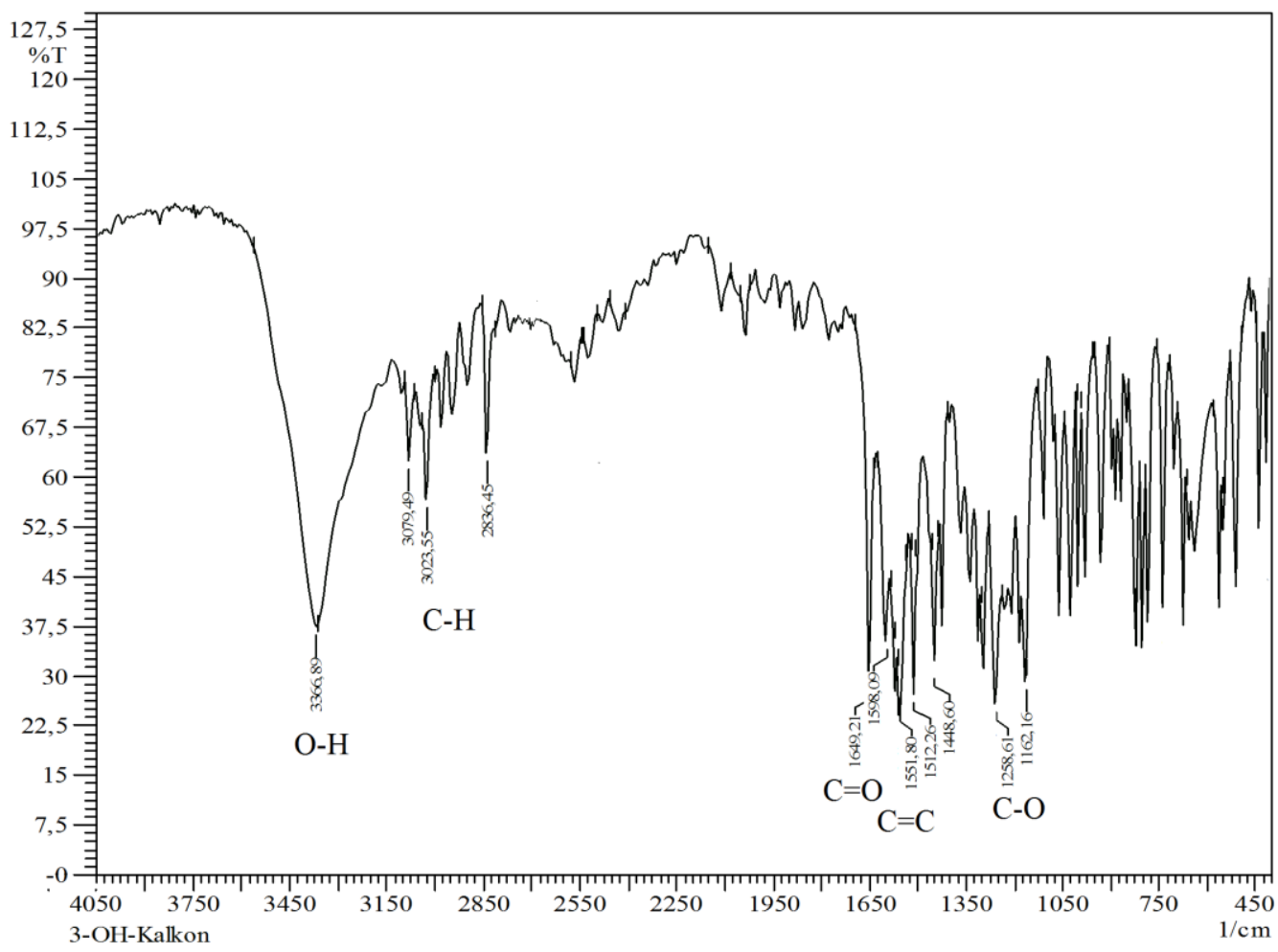

Gambar 3. Spektrum FT-IR senyawa (E)-1-(3-hidroksifenil)-3-(4-metoksifenil)prop-2-en-1-on

Spektrum ${ }^{1} \mathrm{H}$ NMR senyawa hasil sintesis juga menunjukkan sinyal-sinyal proton ekivalen pada daerah pergeseran kimia aromatik yang merupakan ciri khas gugus fenil tersubstitusi dimana substituen tersebut terletak pada posisi para. Puncak doublet pada pergeseran kimia 7,59 ppm (2H) dan 6,93 ppm $(2 \mathrm{H})$, masing-masing merupakan sinyal dari proton aromatik $2 / 6$ dan $3 / 5$ yang terikat pada cincin $B$ senyawa analog kalkon, sedangkan puncak singlet pada pergeseran kimia 7,62 ppm $(1 \mathrm{H})$ merupakan sinyal dari proton aromatik 2' yang terikat pada cincin A, yang menunjukkan bahwa gugus $\mathrm{OH}$ pada cincin A dari senyawa analog kalkon tersebut terletak pada posisi meta.

Selanjutnya, analisis spektrum massa resolusi tinggi dilakukan untuk mengkonfirmasi masa molekul dari senyawa analog kalkon hasil sintesis. Berdasarkan hasil analisis spektrum massa, senyawa hasil sintesis memiliki massa yang sesuai dengan senyawa target. Puncak ion molekul $\left[\mathrm{M}+\mathrm{H}^{+}\right]$senyawa analog kalkon pada spektrum MS ditemukan pada $\mathrm{m} / \mathrm{z}$ 255,1024 dengan selisih massa sebesar 0,0003 dari massa hasil perhitungan $(255,1021)$, sebagaimana dapat dilihat pada gambar 5 . Selisih massa yang sangat kecil ini menunjukkan bahwa senyawa yang diperoleh mempunyai kemurnian yang baik. 


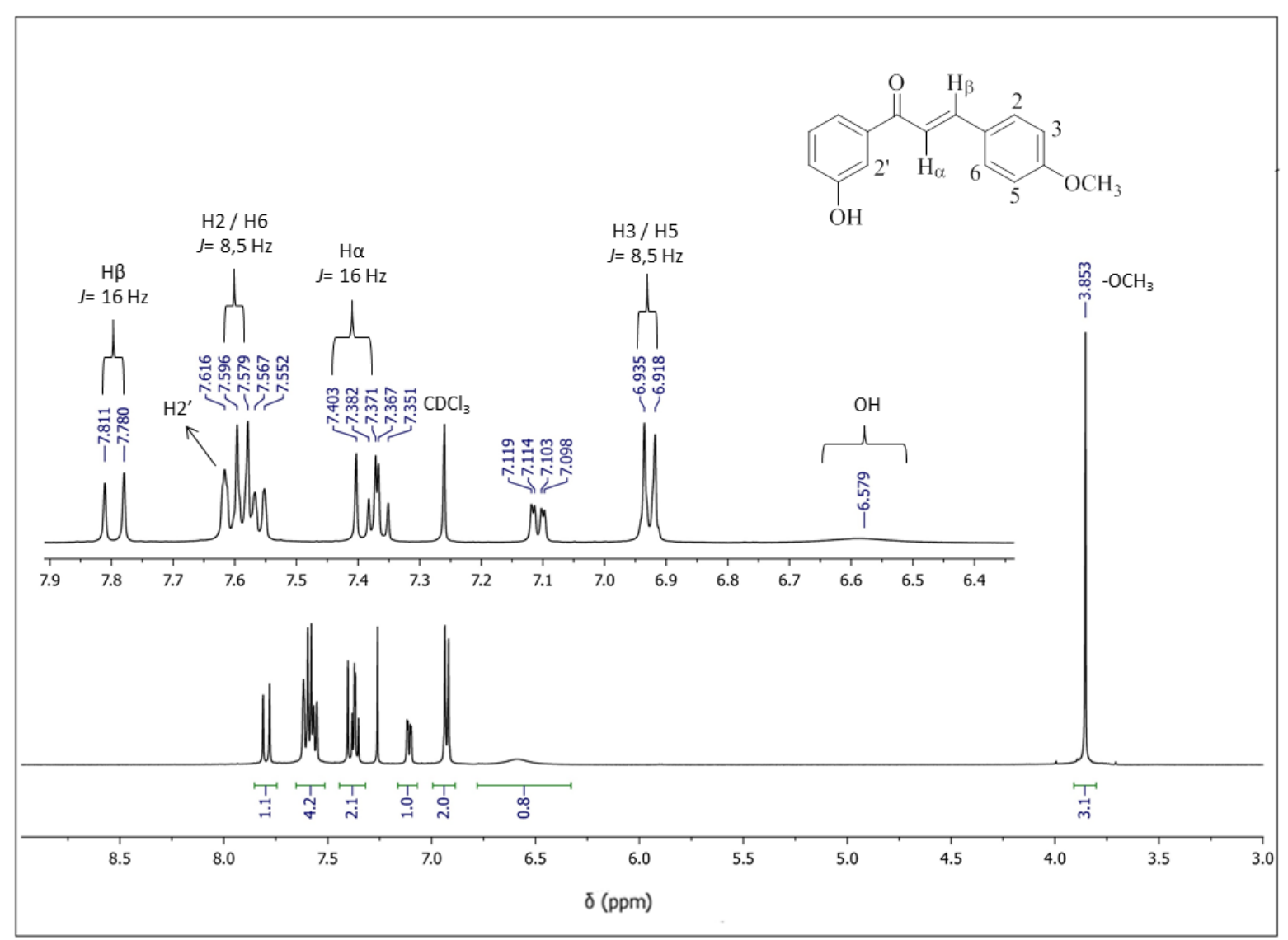

Gambar 4. Spektrum $/{ }^{1} \mathrm{H} \quad \mathrm{NMR} \quad\left(500 \quad \mathrm{MHz}, \quad \mathrm{CDCl}_{3}\right)$ senyawa $\quad($ E)-1-(3-hidroksifenil)-3-(4metoksifenil)prop-2-en-1-on

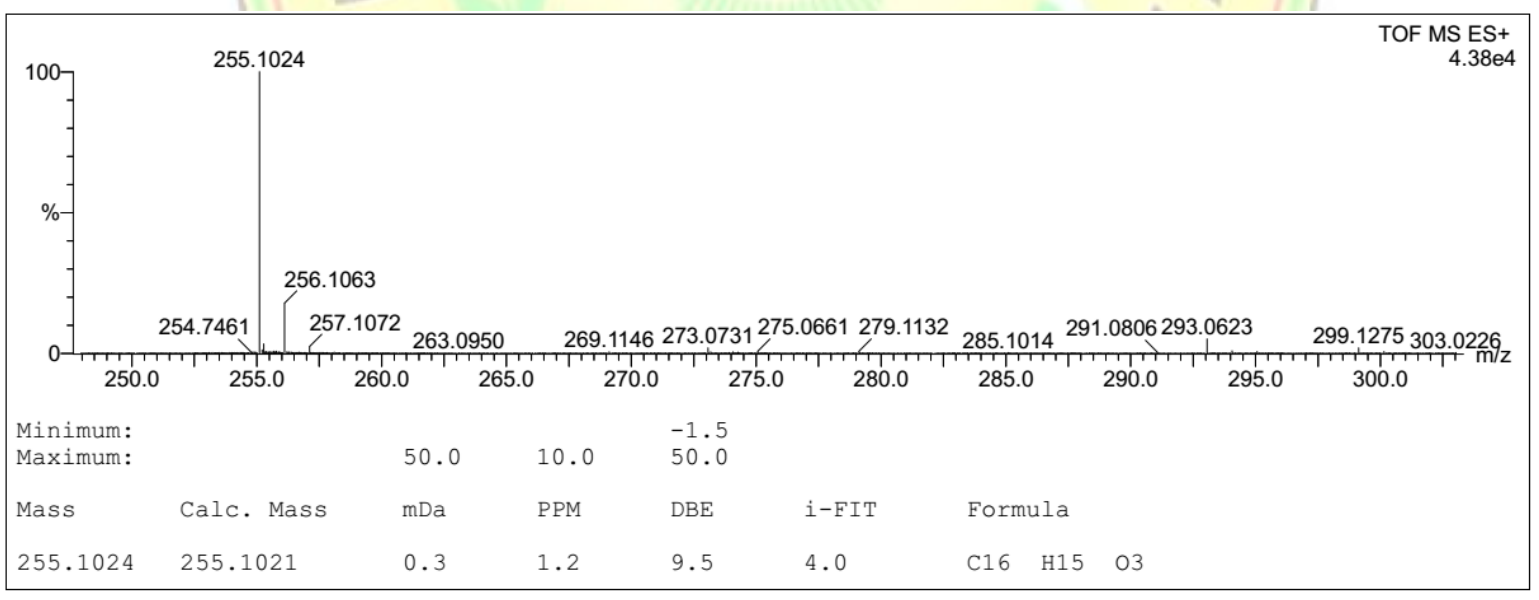

Gambar 5. Spektrum HRMS senyawa (E)-1-(3-hidroksifenil)-3-(4-metoksifenil)prop-2-en-1-on Uji aktivitas tabir surya secara in vitro

Pengujian aktivitas tabir surya dilakukan secara in vitro menggunakan microplate reader. Pengujian ini meliputi penentuan nilai \%Te, \%Tp dan nilai SPF. Nilai \%Te adalah nilai yang menggambarkan kemampuan suatu zat untuk memproteksi kulit dari sinar UV yang dapat menyebabkan kemerahan pada kulit (eritema) yaitu jumlah energi sinar UV yang diteruskan pada radiasi UV B (290-320 nm). Sedangkan pengukuran nilai \% Tp dilakukan untuk mendapatkan nilai yang menggambarkan kemampuan suatu zat untuk memproteksi kulit dari sinar UV yang dapat menyebabkan proses penggelapan pada kulit 
(pigmentasi) disebabkan oleh jumlah energi sinar UV yang diteruskan pada radiasi UV A (320-375 $\mathrm{nm}$ ) (Hasanah et al., 2015). Semakin rendah nilai \% Te dan \% Tp suatu zat menunjukkan bahwa semakin kecil pula intensitas sinar UV yang diteruskan ke kulit, dengan kata lain semakin baik potensi zat tersebut untuk melindungi kulit dari paparan sinar UV. Hasil pengukuran nilai \%Te dan \%Tp senyawa analog kalkon (E)1-(3-hidroksifenil)-3-(4-metoksifenil)prop-2-en-1-on dapat dilihat pada tabel 2. Berdasarkan tabel tersebut, dapat diliat bahwa pada konsentrasi uji tertinggi $(500 \mu \mathrm{g} / \mathrm{ml})$ senyawa analog kalkon tersebut memiliki nilai $\%$ Te dan \% $\mathrm{Tp}<1 \%$, sehingga kekuatan proteksiya dapat dikategorikan sebagai sunblock (Athiyah et al., 2015), sedangkan pada konsentrasi uji terendah $(100 \mu \mathrm{g} / \mathrm{ml})$, senyawa tersebut memiliki nilai \% Te sebesar $5,49 \%$ (proteksi ekstra) dan nilai \% Tp $<1 \%$ (sunblock).

Tabel 2. Hasil penentuan nilai \% Te dan \% Tp senyawa analog kalkon

\begin{tabular}{cccc}
\hline $\begin{array}{c}\text { Konsentrasi } \\
(\mu \mathrm{g} / \mathrm{ml})\end{array}$ & Nilai \% Te & Nilai \% Tp & Kategori Tabir Surya \\
\hline 500 & $0,04 \pm 0,00$ & $0,05 \pm 0,00$ & sunblock \\
400 & $0,04 \pm 0,00$ & $0,05 \pm 0,00$ & sunblock \\
300 & $0,06 \pm 0,01$ & $0,05 \pm 0,00$ & sunblock \\
200 & $0,43 \pm 0,08$ & $0,06 \pm 0,00$ & sunblock \\
100 & $5,49 \pm 0,12$ & $0,51 \pm 0,02$ & proteksi ekstra - sunblock \\
\hline
\end{tabular}

Tabel 3. Hasil penentuan nilai SPF senyawa analog kalkon

\begin{tabular}{ccl}
\hline $\begin{array}{c}\text { Konsentrasi } \\
(\mu \mathrm{g} / \mathrm{ml})\end{array}$ & Nilai SPF & Kekuatan Proteksi \\
\hline 500 & $32,91 \pm 0,01$ & proteksi ultra \\
400 & $32,89 \pm 0,06$ & proteksi ultra \\
300 & $32,74 \pm 0,01$ & proteksi ultra \\
200 & $30,61 \pm 0,38$ & proteksi ultra \\
100 & $18,20 \pm 0,51$ & proteksi ultra \\
\hline
\end{tabular}

Kemudian, pengukuran nilai SPF dilakukan untuk mengetahui ukuran kemampuan tabir surya untuk untuk melindungi kulit dari paparan sinar matahari. Nilai SPF menyatakan berapa kali daya tahan alami kulit seseorang dilipatgandakan sehingga aman di bawah matahari tanpa terkena luka bakar (Wala et al., 2015). Semakin tinggi nilai SPF, menunjukkan potensi tabir surya yang semakin baik. Hasil penentuan nilai SPF senyawa analog kalkon (E)-1-(3-hidroksifenil)-3-(4-metoksifenil)prop-2-en-1-on dapat dilihat pada tabel 3. Berdasarkan perhitungan, diperoleh hasil bahwa pada semua konsentrasi uji (100-500 $\mu \mathrm{g} / \mathrm{ml})$, senyawa analog kalkon tersebut memiliki nilai $S P F \geq 15$, sehingga kekuatan proteksi senyawa analog kalkon tersebut dapat dikategorikan sebagai proteksi ultra (Sami et al., 2015). Kemudian berdasarkan data pada tabel 2 dan tabel 3, dapat dilihat bahwa pada konsentrasi $200 \mu \mathrm{g} / \mathrm{ml}$, senyawa uji sudah dapat memberikan perlindungan dengan kategori sunblock dengan nilai \%Te sebesar 0,43 \pm 0,08\% dan nilai \%Tp sebesar 0,06 $\pm 0,00 \%$. Selain itu, pada konsentrasi tersebut senyawa uji juga sudah dapat menunjukkan proteksi ultra dengan nilai SPF sebesar 30,61 $\pm 0,38$. 


\section{KESIMPULAN}

Pada penelitian ini, senyawa analog kalkon (E)-1-(3-hidroksifenil)-3-(4-metoksifenil)prop-2-en-1-on telah berhasil disintesis menggunakan metode iradiasi microwave dengan rendemen yang cukup baik, yaitu sebesar 71,18 \%. Berdasarkan hasil pengujian in vitro, pada konsentrasi uji $200 \mu \mathrm{g} / \mathrm{ml}$, senyawa analog kalkon tersebut sudah dapat memberikan perlindungan dengan kategori sunblock dengan nilai \%Te sebesar 0,43 $\pm 0,08 \%$ dan nilai \%Tp sebesar 0,06 \pm 0,00 \%. Selain itu, pada konsentrasi tersebut senyawa uji juga sudah dapat menunjukkan proteksi ultra dengan nilai SPF sebesar $30,61 \pm 0,38$. Sehingga dapat disimpulkan bahwa senyawa analog kalkon tersebut berpotensi untuk dikembangkan sebagai bahan aktif pada sediaan tabir surya. Namun demikian, pengujian lebih lanjut masih diperlukan untuk menentukan stabilitas senyawa tersebut di bawah radiasi sinar UV dan juga toksisitas senyawa tersebut terhadap kulit manusia.

\section{UCAPAN TERIMAKASIH}

Peneliti mengucapkan terimakasih kepada Kementrian Riset Teknologi dan Pendidikan Tinggi (KEMENRISTEK DIKTI) atas bantuan pendanaan yang diberikan untuk riset ini melalui hibah Penelitian Dosen Pemula (PDP) tahun 2019 dengan nomor kontrak penelitian 06.15.LP2M.STIFAR.V.2019.

\section{DAFTAR PUSTAKA}

Athiyah, M., Ahmad I., dan Rijai, L. 2015. Aktivitas Tabir Surya Ekstrak Akar Bandotan (Ageratum conyzoides). Jurnal Sains dan Kesehatan, 1(4), 181- 187.

Balsam, M.S. dan Sagarin, E. 1972. Cosmetics: Science and Technology $2^{\text {nd }}$ Ed., Vol. 1-3. New York: Interscience Publishers Inc.

Bhuiyan, M.M.H., Hossain, M.I., Mahmud, M.M., dan Al-Amin, M. 2011. Microwave-assisted efficient synthesis of chalcones as probes for antimicrobial activities. J. Chem., 1(1), 21-28.

Britton, R.G., Horner-Glister, E., Pomenya, O.A., Smith, E.E., Denton, R., Jenkins, P.R., Steward, W.P., Brown, K., Gescher, A., dan Sale, S. 2012. Synthesis and biological evaluation of novel flavonols as potential anti-prostate cancer agent. European Journal of Medicinal Chemistry, 54, 952-958.

Downs, C.A., Kramarsky-Winter, E., Segal, R., Fauth, J., Knutson, S., Bronstein, O., Ciner, F.R., Jeger, R., Lichtenfeld, Y., dan Woodley, C.M., 2016. Toxicopathological effects of the sunscreen UV filter, oxybenzone (benzophenone-3), on coral planulae and cultured primary cells and its environmental contamination in Hawaii and the U.S. Virgin Islands. Arch. Environ. Contam. Toxicol., 70, 265288.

Dutra, E.A., Daniella, A.C.C., Erika, R.M.K., dan Maria, I.R.M.S. 2004. Determination of Sun Protection Factor (SPF) of Sunscreen by UV Spectrophotometry. Brazilian journal of Pharmaceutical Sciences, 40(3), 381-385

Forestier, S., Moire, C., dan Lang, G. 1986. Cosmetic composition containing hydroxylated chalcone derivatives and its use for protecting the skin and the hair against luminous radiations, new hydroxylated chalcone derivatives employed and process for their preparation. US4867964A.

George, F., dan Fellague, T. 2003. Chemical compound consisting of a nitrogenous chalcone derivative, method of producing on such chemical compound and filtering and/or cosmetics composition containing same. WO 2003097577.

Hasanah, S., Ahmad, I., dan Rijai, L. 2015. Profil Tabir Surya Ekstrak dan Fraksi Daun Pidada Merah (Sonneratica caseolaris L.), Jurnal Sains dan Kesehatan, 1(4), 175-180.

Holick, M.F. 2008. Vitamin D and sunlight: Strategies for cancer prevention and other health benefits. Clin. 


\section{J. Am. Soc. Nephrol, 3, 1548-1554.}

Hossein-nezhad, A. dan Holick, M.F. 2013. Vitamin D for health: A global perspective. Mayo Clin. Proc., 88, 720-755.

Ikhtiarudin, I., Lelani, Zamri, A., Teruna, H.Y., dan Yuharmen. 2014. Sintesis dan uji toksisitas senyawa analog kalkon turunan 2'-hidroksiasetofenon dan halobenzaldehid. Jurnal Photon, 5(1), 57-63.

Jung, J-C., Lee, Y., Min, D., Jung, M., dan Oh, S. 2017. Practical synthesis of chalcone derivatives and their biological activities. Molecules 2017, 22, 1872.

Kabira, E., Kumar, P., Kumar, S., Adelodun, A.A., dan Kim, K-H. 2018. Solar energy: Potential and future prospects. Renewable and Sustainable Energy Reviews, 82, 894-900.

Karlsson, I., Hillerstrom, L., Stenfeldt, A.L., Martensson, J., dan Borje, A. 2009. Photodegradation of dibenzoylmethanes: Potential cause of photocontact allergy to sunscreens. Chem. Res. Toxicol. 22, 1881-1892.

Lahorkar, P.G.R., Vaidya, A.A., Chavan, M.V., dan Gadgil, V.R. 2014. A photoprotective personal care composition. PCT Int. Appl. WO 2014191143-A1 20141204.

Lazópulos, L.Q., Svarc, F., Sagrera, G., dan Dicelio, L. 2018. Absorption and Photo-Stability of Substituted Dibenzoylmethanes and Chalcones as UVA Filters. Cosmetics, 5, 33.

Mansur, J.S., Breder, M.N.R., Mansur, M.C.A. dan Azulay, R.D. 1986. Determinação Do Fator De Proteção Solar Por Espectrofotometria. An Bras Dermatol Rio De Janeiro, 61, 121-124.

Patil, C.B., Mahajan, S.K., dan Katti, S.A. 2009. Chalcone: a versatile molecule. Journal of Pharmaceutical Science and Research, 1(3), 11-12.

Rateb, N.M. dan Zohdi, H.F. 2009. Atom-efficient, solvent-free, green synthesis of chalcones by grinding. Synthetic Communications, 39, 2789-2794.

Razzaq, T. dan Kappe, C.O. 2008. On the energy efficiency of microwave-assisted organic reactions. Chem Sus Chem, 1, 123-132.

Sahu, N.K., Balbhadra, S.S., Choudhary, J., dan Kohli, D.V. 2014. Exploring pharmacological significance of chalcone scaffold: a review. Curr Med Chem., 19, 209-225.

Sami, F.J., Nur, S., dan Martani, M.M. 2015. Uji Aktivitas Tabir Surya pada Beberapa Spesies dari Family Zingiberaceae dengan Metode Spektrofotometri. As-syifaa, 7(2): 164-173.

Sayre, R.M., Dowdy, J.C., Gerwig, A.J., Shields, W.J., dan Lloyd, R.V. 2005. Unexpected photolysis of the sunscreen octinoxate in the presence of the sunscreen avobenzone. Photochem. Photobiol., 81, 452456.

Schwack, W., dan Rudolph, T. 1995. Photochemistry of dibenzoylmethane UVA filters, Part I. J. Photochem. Photobiol. B, 28, 229-234.

Shaath, N.A. 2005. Sunscreen evolution. In Sunscreens, Regulations and Commercial Development. Boca Raton, FL, USA: Taylor \& Francis.

Shaath, N.A. 2010. Ultraviolet filters. Photochem. Photobiol. Sci., 9, 464-469.

Stoyanov, E.V., Champavier, Y., Simon, A., dan Basly J-P. 2002. Efficient liquid-phase synthesis of 2'hydroxychalcones. Bioorganic \& Medicinal Chemistry Letters, 12, 2685-2687.

Tovar-Sanchez, A., Sanchez-Quiles, D., Basterretxea, G., Benede, J.L., Chisvert, A., Salvador, A., MorenoGarrido, I., dan Blasco, J. 2013. Sunscreen products as emerging pollutants to coastal waters. PLoS ONE, 8, e65451.Lahorkar, P.G.R., Vaidya, A.A., Chavan, M.V., dan Gadgil, V.R. 2014. A Photoprotective Personal Care Composition. PCT Int. Appl. WO $2014191143-A 120141204$.

Wala, M.E., Edy, S., Defny, S. W. 2015, Aktivitas Antioksidan dan Tabir Surya Fraksi dari Ekstrak Lamun 
(Syringodium isoetifolium), PHARMACON Jurnal Ilmiah Farmasi, 4(4) : 282-289.

Wang, S.Q, Stanfield, M.S, dan Osterwalder, U. 2008, In Vitro Assessment of UV A Protection by Populer Sunscreen Available in the United States. Journal of America Dermatology, 3(2): 56-67.

Zamri, A., Teruna, H.Y., dan Ikhtiarudin, I. 2016. Pengaruh variasi daya terhadap selektivitas reaksi sintesis analog 2'-hidroksicalkon menggunakan iradiasi gelombang mikro. Molekul, 11(2), 299-307.

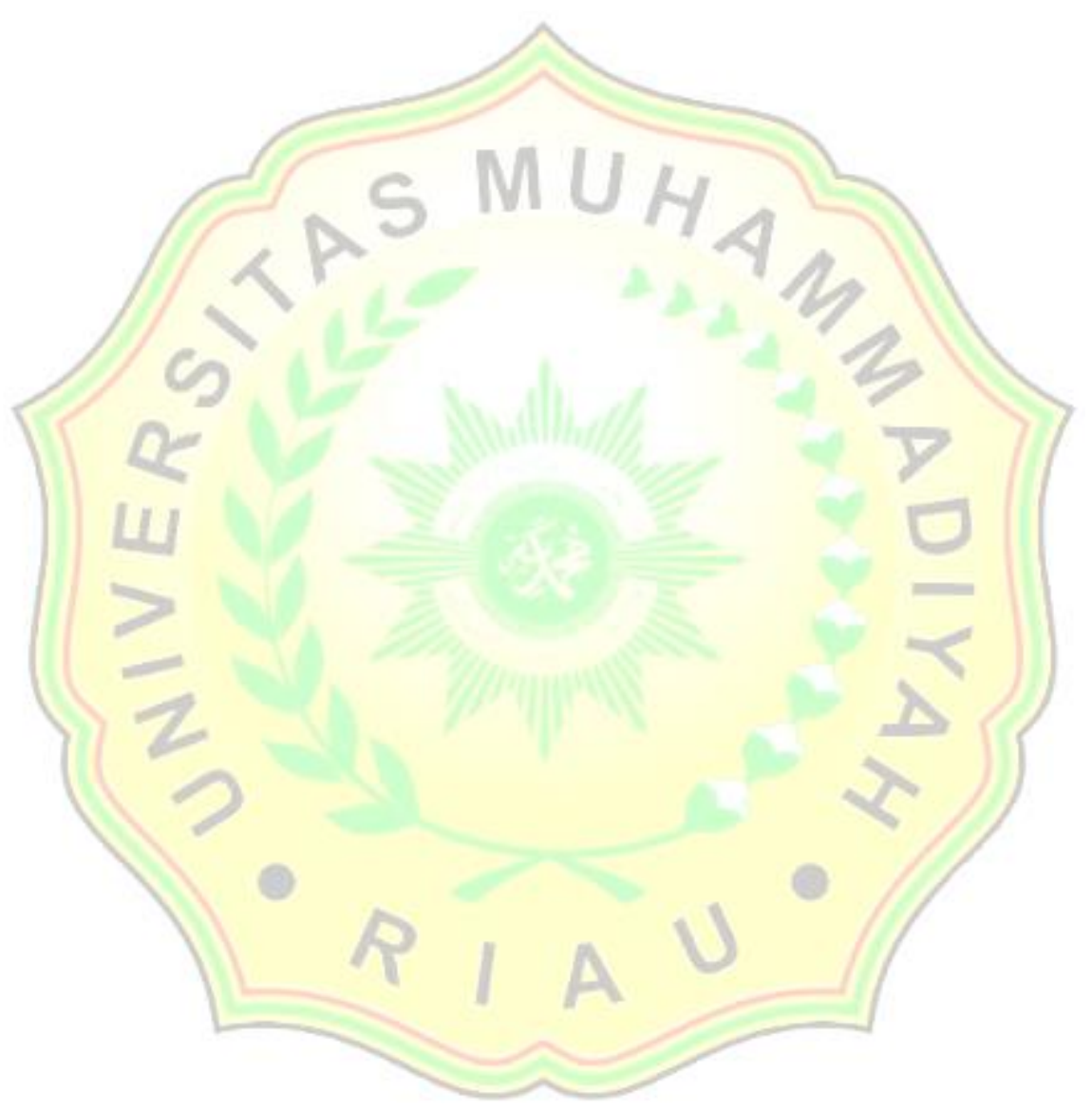

